\title{
Biodiversity and distribution of the genus Gromia (Protista, Rhizaria) in the deep Weddell Sea (Southern Ocean)
}

\author{
Nina Rothe • Andrew J. Gooday • \\ Tomas Cedhagen $\cdot \mathbf{J}$. Alan Hughes
}

Received: 12 March 2010 / Revised: 22 June 2010 / Accepted: 23 June 2010 / Published online: 10 July 2010

(C) Springer-Verlag 2010

\begin{abstract}
We present a survey of morphospecies of Gromia, a genus of testate protists, from bathyal and abyssal depths in the Weddell Sea and adjacent areas of the Southern Ocean. This material represents the most extensive and diverse available collection of deep-sea gromiids so far recorded. The twelve species, nine of which are undescribed, are recognized on the basis of morphological criteria, including the test size and shape, the appearance and structure of the oral capsule, and the characteristics of the test wall. Most species have a single oral capsule, which is circular in plan view with a conical nipple-like shape in lateral view. One morphospecies has three oral capsules. The appearance and structure of the wall displays great variability among Gromia species, ranging from very delicate and transparent with highly reflective highlights to relatively thick with distinct patterns of ridges covering the surface. More often, however, differences in wall structure are more subtle. Most morphospecies were distributed at bathyal depths along the continental margin, but one was sampled at $\sim 4,800 \mathrm{~m}$, representing the first record of an abyssal gromiid. Concurrent with findings from other regions of the World's oceans, the Weddell Sea gromiids were mostly found in surficial sediments in areas of elevated organic input, suggesting that deep-sea gromiids are likely to play an important role in carbon cycling in bathyal eutrophic regions through the ingestion and degradation of fresh organic matter.
\end{abstract}

\footnotetext{
N. Rothe $(\bowtie) \cdot$ A. J. Gooday · J. Alan Hughes

National Oceanography Centre,

Southampton SO14 3ZH, UK

e-mail: nr3@noc.soton.ac.uk

T. Cedhagen

Biologisk Institut, Aarhus Universitet,

Finlandsgade 14, 8200 Århus N, Denmark
}

Keywords ANDEEP - Morphological diversity · Taxonomic diversity $\cdot$ Biogeography $\cdot$ Bathymetric distribution

\section{Introduction}

Gromiids are large amoeboid protozoans in which the cytoplasm is enclosed by a proteinaceous test. The cell body extends into thin, pointed branching extensions of the cytoplasm (filose pseudopodia) that protrude from the test through an aperture that is surrounded by an oral capsule, a characteristic feature of the group (Hedley 1960; Ogden and Hedley 1980). The tests of gromiids are also characterized by multiple layers of so-called honeycomb membranes that line the inner surface of the wall. These were first described by Hedley and Wakefield (1969) in Gromia oviformis Dujardin 1835 , a shallow-water species ubiquitously distributed in environments ranging from polar shelves to tropical coral reefs. Another feature of gromiids is the accumulation of a significant volume of stercomata (waste pellets), together with mineral grains and other extraneous particles, within the cell. For many years, these poorly known protozoans were believed to be restricted to intertidal and sublittoral waters (Arnold 1951, 1972; Bowser et al. 1996; Gooday et al. 1996, 2005). The deepest record for Gromia oviformis is from $270 \mathrm{~m}$ off South Georgia (Arnold 1972). These shallow-water gromiids, most of them assigned to Gromia oviformis, are associated with various habitats and sediment types including hard substrata such as rock surfaces (Hedley and Bertaud 1962), the holdfast of seaweeds (Arnold 1972), and the surfaces of sandy and muddy sediments (Jepps 1926; Hedley and Bertaud 1962; Bowser et al. 1996).

The first convincing record of Gromia from deeper waters is that of Schulze (1875) who described Gromia sp. 
sampled in Bukenfjord and Korsfjord, Norway between 185 and $675 \mathrm{~m}$ depth. This species, which was later named G. schulzei by Norman (1892), has a mound-like oral capsule and contains stercomata within the cell. It has an elongate test up to $8-9 \mathrm{~mm}$ in length, making it substantially larger than the grape-shaped G. oviformis (length 0.15$5.0 \mathrm{~mm}$ ). The first record of gromiids inhabiting the deep sea below 1,000 $\mathrm{m}$ was from the Oman margin of the Arabian Sea, where they were discovered in 1994 below the main part of the oxygen minimum zone (OMZ) (Gooday et al. 2000). Gromiids were found subsequently on the other side of the Arabian Sea, off Pakistan (Aranda da Silva and Gooday 2009). Two species, G. sphaerica Gooday, Bowser, Bett, Smith 2000 and G. pyriformis Gooday and Bowser 2005, were formally described based on this Arabian Sea material, and eight additional undescribed species were recognized based on partial small-subunit ribosomal DNA (SSU rDNA) gene sequences (Aranda da Silva et al. 2006). Recently, Matz et al. (2008) identified G. sphaerica at $\sim 750 \mathrm{~m}$ depth off the Bahamas. A "faecal pellet" from $1,130 \mathrm{~m}$ depth in the Catalina Basin on the California borderland, illustrated by Jumars (1976), closely resembles one of the elongate gromiids from the Arabian Sea (Gooday et al. 2000; Aranda da Silva 2005).

Gromiids have also been found in other deep-water areas including the deep fjords of Svalbard in the European Arctic (Gooday et al. 2005) and $923 \mathrm{~m}$ under the Ross Ice Shelf, Antarctica (Pawlowski et al. 2005). In addition, sixteen undescribed morphospecies were recently recognized from the Northwest African margin, the Porcupine Seabight and the Rockall Trough (Northeast Atlantic), as well as from the deep Skagerrak and four western Norwegian fjords (Rothe 2009). During the 2005 ANDEEP III expedition, a large number of gromiids were collected from bathyal and abyssal sites in the Weddell Sea and adjacent areas of the Southern Ocean (Gooday et al. 2006). Based on this material, three species, G. marmorea Rothe \& Gooday 2009, G. melinus Rothe \& Gooday 2009, and G. winnetoui Rothe \& Gooday 2009, were formally described by Rothe et al. (2009). Nine additional undescribed species were also recognized. This paper describes the diversity and distribution of gromiids in these samples from the Southern Ocean.

\section{Materials and methods}

Study area

The ANDEEP project encompassed three cruises onboard the RV Polarstern, the first and second cruises taking place in 2001 (ANDEEP I and II; Polarstern Cruise ANT XIX/3-4) and the third in 2005 (ANDEEP III; Polarstern Cruise ANT XXII/3). The samples used in this study originate from this final ANDEEP cruise (Table 1, Fig. 1).

Sampling, shipboard processing, and preservation

The material investigated was recovered either with an epibenthic sledge (EBS), an Agassiz trawl (AGT), or with a multicorer (MUC, 57-mm inner tube diameter) (Fahrbach 2006, Rose et al. 2006). The EBS was equipped with a 1 -m-wide lower epibenthic net $(500-\mu \mathrm{m}$ mesh size) and a 1 -m-wide upper suprabenthic net $(300-\mu \mathrm{m}$ mesh size). The AGT was $3 \mathrm{~m}$ wide and equipped with a cod end with a mesh size of $500 \mu \mathrm{m}$, except at Station 81 where the mesh size was $10 \mathrm{~mm}$. Both EBS and AGT were trawled along the seafloor for 10 min with a mean velocity of 1 knot (Fahrbach 2006). Once onboard the ship, samples were kept submerged in chilled water and sieved in a cool room
Table 1 Sample stations, deployments, positions, depth, gear (EBS = epibenthic sledge, AGT $=$ Agassiz trawl, MUC $=$ multicorer), number of specimens sampled. WSAP Weddell Sea Abyssal Plain

\begin{tabular}{|c|c|c|c|c|c|}
\hline Station & Latitude (S) & Longitude (W) & Depth (m) & Gear & \# Of specimens \\
\hline \multicolumn{6}{|c|}{ Powell Basin } \\
\hline 133 & $62^{\circ} 46.94$ & $53^{\circ} 1.72$ & 1,584 & EBS & $\sim 700$ \\
\hline 121 & $63^{\circ} 37.43$ & $50^{\circ} 45.11$ & 2,600 & AGT & 36 \\
\hline 150 & $61^{\circ} 48.32$ & $47^{\circ} 28.45$ & 1,970 & AGT & 7 \\
\hline 151 & $61^{\circ} 45.56$ & $47^{\circ} 7.55$ & 1,180 & AGT, MUC & 1 \\
\hline \multicolumn{6}{|c|}{ Bellinghausen Sea } \\
\hline 153 & $63^{\circ} 19.20$ & $64^{\circ} 37.07$ & 2,108 & AGT & 8 \\
\hline \multicolumn{6}{|l|}{ WSAP } \\
\hline 102 & $65^{\circ} 33.16$ & $36^{\circ} 33.32$ & 4,800 & EBS & 2 \\
\hline \multicolumn{6}{|c|}{ Kapp Norvegia } \\
\hline 80 & $70^{\circ} 39.07$ & $14^{\circ} 43.36$ & 3,108 & EBS & 13 \\
\hline 81 & $70^{\circ} 32.02$ & $14^{\circ} 35.05$ & 4,392 & EBS & 3 \\
\hline \multicolumn{6}{|c|}{ Neumayer Slope } \\
\hline 57 & $69^{\circ} 24.50$ & $5^{\circ} 19.37$ & 1,891 & AGT & 12 \\
\hline
\end{tabular}


Fig. 1 Cruise track during RV Polarstern leg ANT-XXII/3 from 21 January 2005 to 6 April 2006. Circles indicate gromiid sample stations

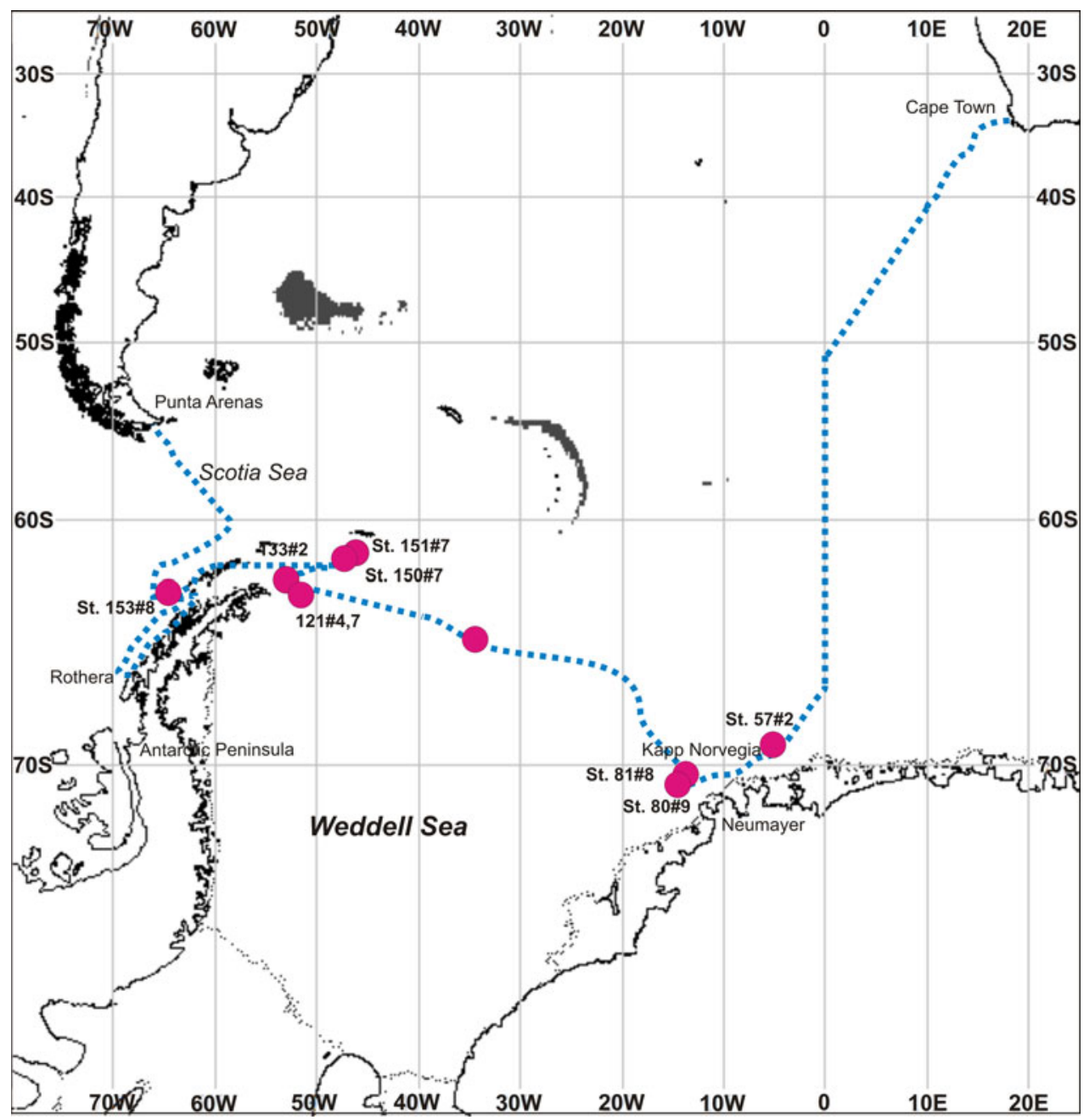

on sieves of mesh sizes 500 and $300 \mu \mathrm{m}$. These unfixed sediment residues were sorted under a Leica binocular microscope for foraminifera and gromiids as soon as possible after collection. During this process, the residues were kept cool by placing the sorting dish in another dish filled with ice. Photographs of picked specimens were taken using a Nikon CoolPix 4500 digital camera attached to the microscope. Gromiids were fixed in $10 \%$ buffered formalin for subsequent morphological analysis or frozen in liquid nitrogen for molecular analysis (Gooday et al. 2006).

Morphological species documentation in the laboratory

Gromiids were divided into preliminary morphotypes based on test characteristics and general appearance during the shipboard sorting (Gooday et al. 2006). Later, in the laboratory in Southampton, specimens from each group and station were counted, measured (width and length of test and oral capsule), and examined under a binocular dissecting microscope. Specimens were documented using a SLR digital camera (Canon EOS 350D). General views of the test were obtained using a Leica binocular microscope with the specimens immersed in water in a petri dish. Detailed views of the aperture and other features were taken using an Olympus BH-2 compound microscope with the specimen placed in water in a cavity slide. The subsequent comparison of wall and apertural structures in each individual resulted in the regrouping of specimens based on these morphological features.

\section{Observations and discussion}

Morphological diversity of Weddell Sea Gromia

Despite their unusually large size for single-celled organisms, gromiids are marked by a paucity of taxonomically useful morphological characters. However, features such as test size and shape, the oral capsule, and the appearance and structure of the wall can be used to discriminate between species. Gromiids can vary significantly in size. Overall, the Weddell Sea gromiids ranged from $0.4 \mathrm{~mm}$ (Sp. 154) to $8.5 \mathrm{~mm}$ (Sp. 297) in maximum dimension (Table 2, Fig. 2). Gromia oviformis can reach up to $5.0 \mathrm{~mm}$ and therefore lies 
Table 2 Main morphological characteristics of nine undescribed species of the genus Gromia from the deep Weddell Sea and adjacent areas of the Southern Ocean as well as G. marmorea, G. melinus, and G. winnetoui previously described in Rothe et al. (2009)

\begin{tabular}{|c|c|c|}
\hline $\begin{array}{l}\text { Gromia } \\
\text { species }\end{array}$ & Morphological characteristics & Occurrence \\
\hline G. marmorea & $\begin{array}{l}\text { Test spherical, droplet-shaped to oval; length } 1.0-3.4 \mathrm{~mm} \text {, width } 0.8-1.9 \mathrm{~mm} \text {, } \\
1 / \mathrm{w} \text { ratio } 0.6-1.9 \text {; wall thin, delicate, and translucent with marble pattern } \\
\text { and pores visible under SEM; oral capsule prominent, pointed } \\
(100-600 \mu \mathrm{m} \text { high, } 200-800 \mu \mathrm{m} \text { wide }) \text {, often with a flaccid extension }\end{array}$ & $\begin{array}{l}\text { 1,584 m, continental slope } \\
\text { Powell Basin (St. 133) }\end{array}$ \\
\hline G. melinus & $\begin{array}{l}\text { Test subtriangular, droplet-shaped, spherical, and asymmetrically rounded; } \\
\text { length } 0.6-1.5 \mathrm{~mm} \text {, width } 0.4-1.4 \mathrm{~mm}, 1 / \mathrm{w} \text { ratio } 1.0-1.5 \text {; the wall robust } \\
\text { with distinctive network of fine ridges and agglutinated clay particles } \\
\text { on surface; oral capsule flat and circular; two capsules in one specimen }\end{array}$ & $\begin{array}{l}\text { 3,108 and } 4,392 \mathrm{~m} \text {; } \\
\text { continental slope off Kapp } \\
\text { Norvegia (Sts. } 80 \text { and } 81 \text { ) }\end{array}$ \\
\hline G. winnetoui & $\begin{array}{l}\text { Test sausage-shaped to elongate oval and irregular; specimens partially } \\
\text { or completely encased in coarsely agglutinated case; length } 1.0-2.8 \mathrm{~mm} \text {, } \\
\text { width } 0.3-0.8 \mathrm{~mm}, 1 / \mathrm{w} \text { ratio } 1.8-8.9 \text {; pores between } 10-50 \mu \mathrm{m} \text { in diameter; } \\
\text { oral capsule conical }(80-120 \mu \mathrm{m} \text { high, } 40-80 \mu \mathrm{m} \text { wide })\end{array}$ & $\begin{array}{l}\text { 2,600 m; continental slope } \\
\text { Powell Basin (St. 121) }\end{array}$ \\
\hline $1 \mathrm{~A}$ & $\begin{array}{l}\text { Test sausage-shaped to elongate oval; length } 3.5-8.5 \mathrm{~mm} \text {, width } 0.4-0.8 \mathrm{~mm} \text {, } \\
\text { 1/w ratio } 2.7-6.1 \text {; posterior end broadly rounded; test tapering towards } \\
\text { oral capsule at bluntly pointed anterior end; oral capsule prominent, } \\
\text { nearly rectangular }(60-140 \mu \mathrm{m} \text { high and wide); transparent test wall thick, } \\
\text { smooth with reflective highlights, thickening where it joins the oral capsule } \\
\text { and comprising several layers (Fig. } 3 \mathrm{a}, \mathrm{b} \text { ) }\end{array}$ & $\begin{array}{l}\text { 1,970 m, continental slope } \\
\text { Powell Basin (St. 150) }\end{array}$ \\
\hline 76 & $\begin{array}{l}\text { Test resembles a bowling-pin with bulbous posterior end and much narrower, more } \\
\text { or less truncated anterior end; length } 1.0-1.6 \mathrm{~mm} \text {, width } 0.2-0.4 \mathrm{~mm}, 1 / \mathrm{w} \text { ratio } \\
4.1-4.7 \text {; small but distinct oral capsule }(20 \mu \mathrm{m} \text { high, } 40 \mu \mathrm{m} \text { wide) with clearly } \\
\text { visible central canal, outer half protrudes from test surface as low mound } \\
\text { with sloping sides; transparent test delicate, undulating surface and diffusive } \\
\text { reflective highlights (Fig. } 3 \mathrm{c}, \mathrm{d})\end{array}$ & $\begin{array}{l}\text { 1,819 m, continental slope } \\
\text { off Kapp Norvegia (St. 57) }\end{array}$ \\
\hline 297 & $\begin{array}{l}\text { Test sausage-shaped with parallel sides and broadly rounded ends; length } \\
2.5-3.6 \mathrm{~mm} \text {, width } 0.5-1.0 \mathrm{~mm}, 1 / \mathrm{w} \text { ratio } 3.5-6.2 \text {; oral capsule protrudes } \\
\text { only slightly from test surface, bordered by thickened part of the wall, } \\
\text { which often forms collar-like structure (height } 40-120 \mu \mathrm{m} \text {, } \\
\text { width } 120-240 \mu \mathrm{m} \text { ); test wall with crinkly surface and closely pressed } \\
\text { against the test contents like cling-film (Fig. } 3 \mathrm{e}, \mathrm{f} \text { ) }\end{array}$ & $\begin{array}{l}2,108 \mathrm{~m} \text {, continental slopes } \\
\text { of Bellinghausen Sea } \\
\text { (St. 153); } 1,582 \mathrm{~m} \\
\text { continental slope } \\
\text { Powell Basin }\end{array}$ \\
\hline 1B & $\begin{array}{l}\text { Test sausage-shaped with more or less parallel sides but tendency to be } \\
\text { somewhat wider at either anterior or posterior end; length } 1.5,1.6 \text {, } \\
\text { and } 3.6 \mathrm{~mm} \text {, width } 0.3,0.4 \text {, and } 0.7 \mathrm{~mm} \text {; oral capsule nipple-like, } \\
\text { bordered by thickened part of the wall; fragile, smooth test wall } \\
\text { with distinct reflective highlights (Fig. } 3 \mathrm{~g}, \mathrm{~h} \text { ) }\end{array}$ & $\begin{array}{l}\text { 1,182 m, continental slope } \\
\text { Powell Basin (St. 150) }\end{array}$ \\
\hline 2 & $\begin{array}{l}\text { Test sausage-shaped, gently curved with rounded posterior end; length } 1.8 \text {, } \\
2.7 \text {, and } 3.0 \mathrm{~mm} \text {, width } 0.5 \text { and } 0.6 \mathrm{~mm} \text {; compact oral capsule oval } \\
\text { in cross-section, protruding as a nipple-like feature from test surface } \\
\text { (height } 20 \text { and } 120 \mu \mathrm{m} \text {, width } 40-120 \mu \mathrm{m} \text { ); test transparent with } \\
\text { polygonal surface pattern and diffuse reflection (Fig. } 3 \mathrm{i}, \mathrm{j} \text { ) }\end{array}$ & $\begin{array}{l}\text { 1,970 m, continental slope } \\
\text { Powell Basin (St. 150) }\end{array}$ \\
\hline $5 \mathrm{~A}$ & $\begin{array}{l}\text { Test varies in shape from nearly spherical to elongate oval with broadly } \\
\text { rounded posterior end; length } 0.5-2.4 \mathrm{~mm} \text {, width } 0.4-0.8 \mathrm{~mm}, 1 / \mathrm{w} \text { ratio } \\
1.1-3.4 \text {; oral capsule oval or subrectangular (height } 20-60 \mu \mathrm{m} \text {, width } \\
20-160 \mu \mathrm{m} \text { ); test wall thin with shiny reflections, in some specimens } \\
\text { translucent with a more diffuse reflection (Fig. } 4 \mathrm{a}-\mathrm{f} \text { ) }\end{array}$ & $\begin{array}{l}\text { 1,970 m, continental slope } \\
\text { Powell Basin (St. 150) }\end{array}$ \\
\hline $5 \mathrm{~B}$ & $\begin{array}{l}\text { Test elongate oval; length } 1.2-2.4 \mathrm{~mm} \text {, width } 0.5-1.6 \mathrm{~mm}, 1 / \mathrm{w} \text { ratio } 1.5-2.4 \\
\text { two or three oral capsules, some surrounded by circular depression; test } \\
\text { composed of two layers, inner layer displays delicate system of fine ridges, } \\
\text { forming irregular network (Fig. } 5 \mathrm{a}-\mathrm{c} \text { ) }\end{array}$ & $\begin{array}{l}\text { 1,970 m, continental slope } \\
\text { Powell Basin (St. 150) }\end{array}$ \\
\hline 145 & $\begin{array}{l}\text { Test spherical, } 1.3-2.5 \mathrm{~mm} \text { diameter; nipple-like oral capsule } \\
\text { (height and width } 100-400 \mu \mathrm{m} \text { ); transparent test wall with bright } \\
\text { reflective highlights (Fig. } 5 \mathrm{~d}, \mathrm{f} \text { ) }\end{array}$ & $\begin{array}{l}\text { 3,108 m, continental slope } \\
\text { off Kapp Norvegia (St. 80); } \\
\text { 2,600 m, continental slope } \\
\text { Powell Basin (St. 121) }\end{array}$ \\
\hline 154 & $\begin{array}{l}\text { Test spherical, } 0.4-0.5 \mathrm{~mm} \text { diameter; oral capsule indistinct, often obscured; } \\
\text { transparent test wall with short, fine filaments imparting somewhat hairy } \\
\text { appearance (Fig. 5f, g) }\end{array}$ & $\begin{array}{l}\text { 2,600 m, continental slope } \\
\text { Powell Basin (St. 121); } \\
\text { 4,800 m Weddell Sea Abyssal } \\
\text { Plain (St. 102) }\end{array}$ \\
\hline
\end{tabular}

1/w, length/width ratio 


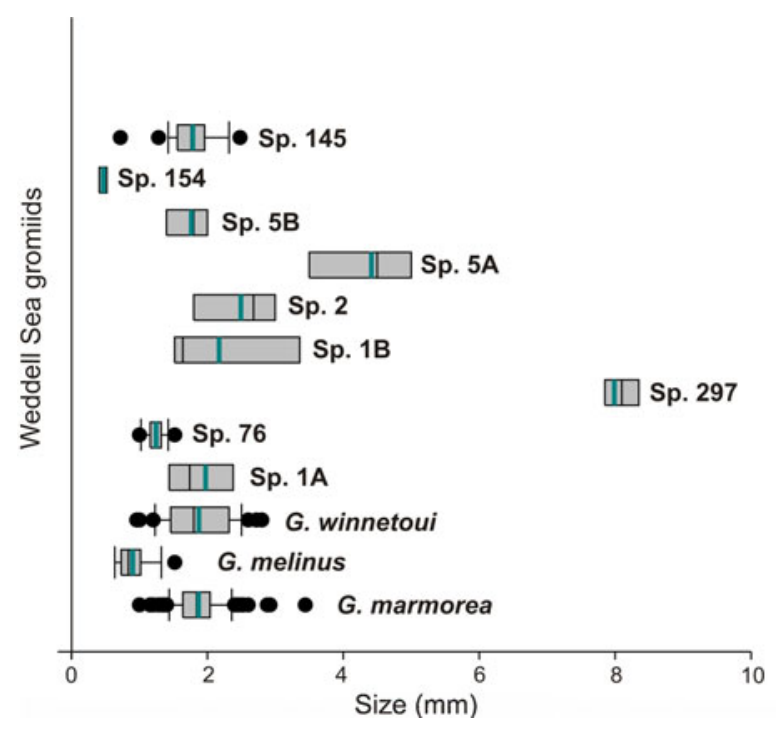

Fig. 2 Size classes of deep-sea gromiids from the Weddell Sea depicted as box plots with 5 th/95th percentile lines, the median (thin vertical line), the mean (thick vertical line) and the outlier (circles)

within the size range of the Southern Ocean (SO) species (Arnold 1951, Hedley 1960). The Arabian Sea species are similar in average size to the SO gromiids but cover a broader size range from $\sim 1 \mathrm{~mm}$ (G. pyriformis) to $4 \mathrm{~cm}$ (G. sphaerica) (Gooday and Bowser 2005, Gooday et al. 2000). Many variables have the potential to influence the size of an individual, including its life history as well as environmental parameters, such as the availability of food. Evidence for a relationship between the size of gromiids and the amount of food available has been presented by Bowser et al. (1996), who noted that G. oviformis from the eutrophic eastern side of McMurdo Sound were bigger than G. oviformis from Explorers Cove on the relatively oligotrophic western side of the Sound. The authors speculated that higher concentrations of organic matter can lead to increased size and population densities in G. oviformis.

Test shape is a more useful character than size for distinguishing deep-sea gromiid species. The main morphotypes recognized from the Weddell Sea and previous studies include spherical (e.g. G. sphaerica-Fig. 2A in Gooday et al. 2000; our Sp. 145 and 154-Table 2 and Fig. 5d, f herein), droplet-shaped (e.g. G. marmorea and G. melinus-Fig. 2A, 5D in Rothe et al. 2009), pear-shaped (e.g. G. pyriformis -Fig. 1 in Gooday and Bowser 2005), grapeshaped (e.g. Sp. 5A-Table 2, Fig. 4a, c herein), elongate oval (e.g. Sp. 5A, 5B-Table 2, Figs. 4e, 5a herein), sausage-shaped (e.g. Sp. 1A, 297, 1B, and 2-Table 2, Fig. 3a, e, g, i herein), bowling-pin shaped (e.g. Sp. 76-Table 2, Fig. 3c herein), as well as irregular (e.g. G. winnetoui and G. melinus-Figs. 7C, 5C in Rothe et al. 2009), and branched (e.g. Species 8-Fig. 3.19 in Aranda da Silva 2005). Within most of these main morphotypes, species exhibit slight differences in shape. For example, some sausage-shaped gromiids can be distinguished by differences in the length/width ratio (Table 2). As with size, there are also variations amongst individuals of one species, although in most cases, interspecific variability is far greater than intraspecific variability. Some Weddell Sea species, however, such as Species 5A (Fig. 4a, c, e), vary more than others, ranging from nearly spherical to elongate oval, whilst others, such as Species 145 and 154, are more consistent in shape (Fig. 5d, f). In the shallow-water species G. oviformis, variations in shape often seem to be a response to the occupancy of a confined microhabitat, for example, the crevices of an algal holdfast, which are not available to sediment-dwelling deep-sea gromiids. Deep-sea environments are much more homogenous compared to most shallowwater habitats, and gromiid species of different shape were sampled from the same station in the Weddell Sea, suggesting that other factors must also play a role in shaping deepsea gromiids.

The shape of the oral capsule is another potentially important taxonomic character. In most gromiids, this structure sits in a shallow, circular depression of the test and is pierced by a central canal leading to the aperture. Most gromiids have one oral capsule, but some have two or three, while G. sphaerica has numerous small apertures scattered across the surface of the test (Gooday et al., 2000). The function of multiple apertures in G. sphaerica is unclear, but they could be related to its spherical shape and mobility. Matz et al. (2008) recently hypothesized that G. sphaerica moves by rolling across the seafloor, a motion presumably facilitated by the sequential deployment of pseudopodia from apertures distributed across the test surface. Several main morphotypes of oral capsule have been observed in the Weddell Sea gromiids. In most species, it is circular in plan view with a conical (e.g. Sp. 1B, 145Figs. 3h, 5e), rectangular (e.g. Sp. 1A-Fig. 3b) or nipplelike shape in lateral view. In many species, the test thickens towards the oral capsule as clearly seen in Sp. 1A (Fig. 3b), Sp. 1B (Fig. 3h), Sp. 5A (Fig. 4b, d, f). Often it has a characteristic form. For example, in Species 297, the oral capsule widens at the top giving it a somewhat flared appearance (Fig. 3f). In Species 2, it is a nearly spherical structure (Fig. 3j), while in Species 76, 5B, and 154, it is very wide and barely protrudes from the test surface (Figs. 3d, 5b, c, g). On the other hand, the oral capsule also varies within a species or it may be very indistinct. Consequently, we consider that the oral capsule should be used with caution as a taxonomic feature to distinguish species.

The appearance and structure of the test wall displays great variability between Gromia species. In the Weddell Sea species, it ranged from very delicate and transparent with highly reflective highlights (e.g. Sp. 2-Table 2, Fig. 3i) to relatively thick with a polygonal pattern of ridges 
Fig. 3 Undescribed species of Gromia. a Reflected light photograph of Species 1A, Station 150, 1,970 m depth; b oral capsule photographed in transmitted light; c reflected light photograph of Species 76, Station 57, 1,819 m depth; $\mathbf{d}$ oral capsule photographed in transmitted light; e reflected light photograph of Species 297, Station 153, 2,108 m depth; f oral capsule photographed in transmitted light; $\mathrm{g}$ reflected light photograph of Species 1B, Station $151,1,140 \mathrm{~m}$ depth; h oral capsule photographed in transmitted light; i reflected light photographs of Species 2, Station 150, 1,970 m depth; $\mathbf{j}$ oral capsule photographed in transmitted light
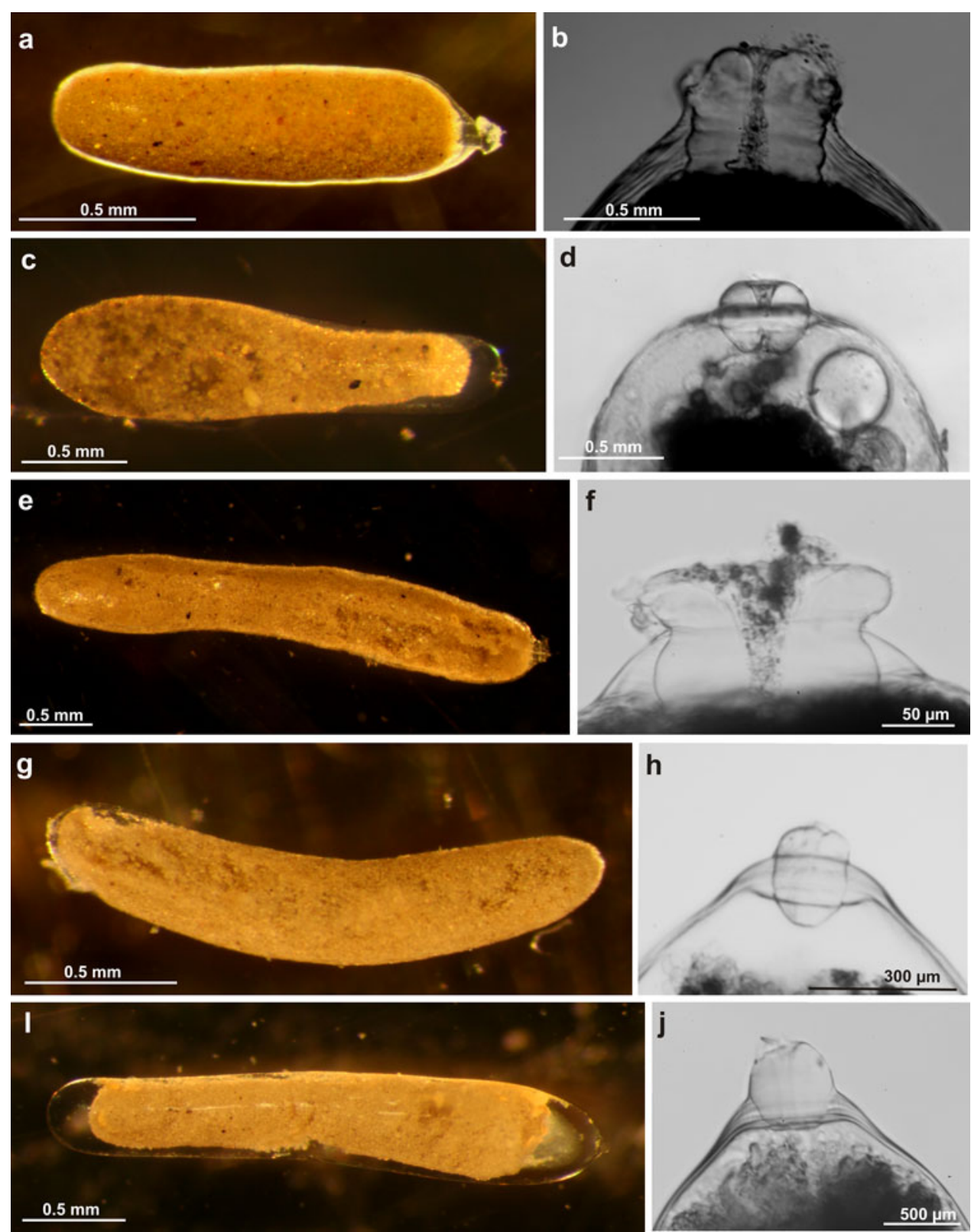

and a layer of clay particles covering the test surface within each polygonal cell, as described in G. melinus by Rothe et al. (2009). In G. winnetoui, an agglutinated case enclosed the organic test, a feature not seen in any other known gromiid species (Fig. 8 in Rothe et al. 2009). Species 154 had a very distinctive hairy appearance, resulting from the presence of thin filaments that extended from the surface (Table 2, Fig. 5f). In most gromiids, however, differences in wall structure were more subtle. For example, in Species $1 \mathrm{~A}$, several layers of the wall were visible, although only in transmitted light, while in Species 2, certain illuminations revealed an indistinct pattern of fine surface ridges. Pore openings were sometimes observed on the test surface in SEM images. These represent the opening of canals that extend through the outer wall and taper towards the exterior (Gooday et al. 2000, Gooday and Bowser 2005). Although these pores were not always visible, it is likely that all gromiids have them. However, their taxonomic and functional significance remains unclear. The wall structure of some gromiids is distinctive at the ultrastructural level. For example, in addition to the Gromia-specific layer of honeycomb membranes (Hedley and Wakefield 1969), the wall of G. pyriformis has an outermost coating, the glycocalyx (75 $\mathrm{nm}$ thick), which has not been reported in other species examined by transmission electron microscopy (TEM) (Gooday and Bowser 2005).

A final feature that may be useful in taxonomy is provided by the test contents, a more or less densely packed 
Fig. 4 Undescribed species of Gromia. a, c, e Reflected light photographs of Species 5A, Station $150,1,970 \mathrm{~m}$ depth (a, c) and Station 153, 2,108 m depth (e); b, d, f oral capsules photographed in transmitted light
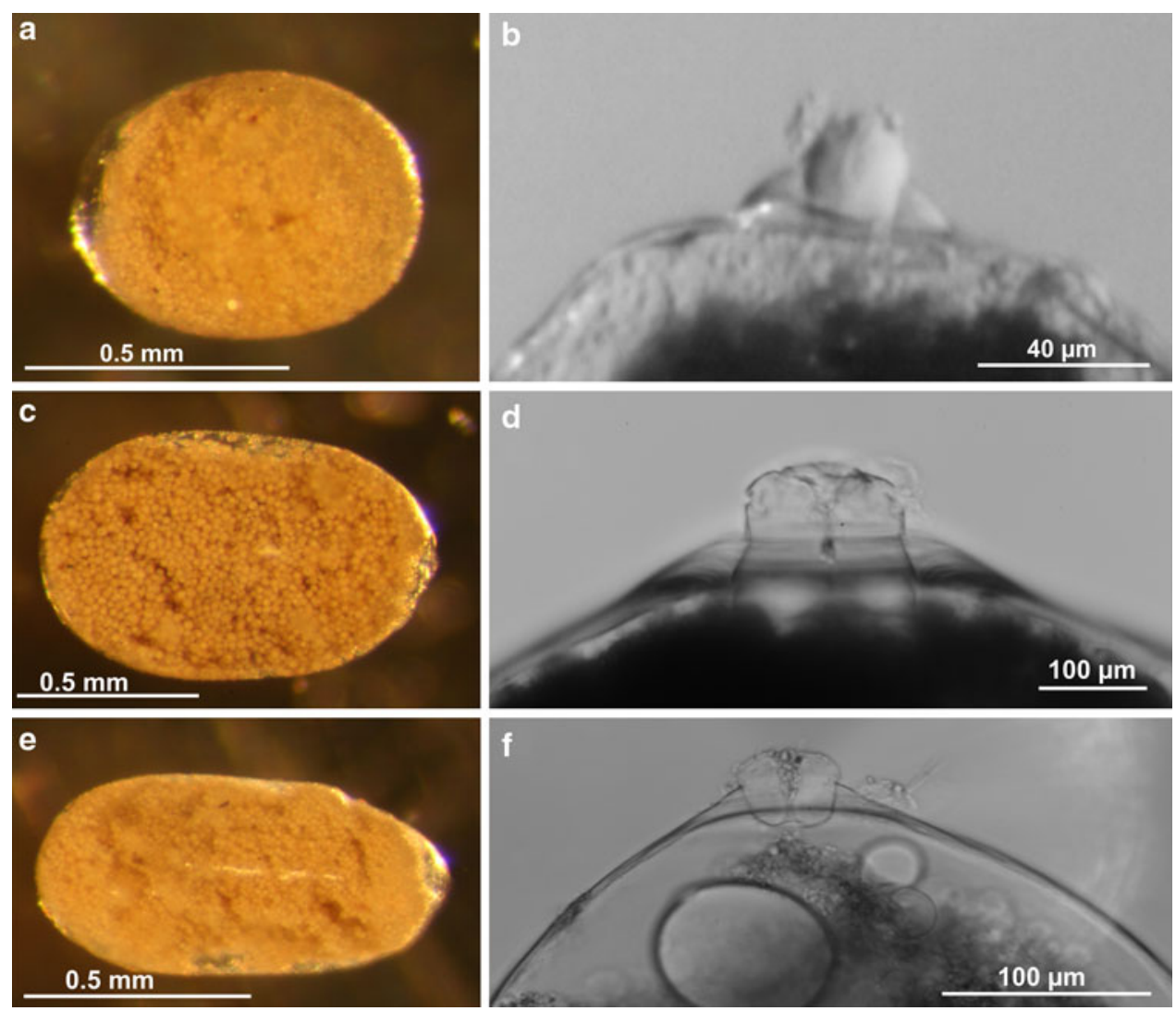

brownish mass of material consisting largely of stercomata. These are small, oval-shaped waste pellets that give some Weddell Sea species a somewhat granular appearance. Stercomata are present in all gromiids but they are not restricted to this group. Their appearance and size is usually fairly similar between species. However, in one species from the Weddell Sea (Species 154), they were unusually large (up to $400 \mu \mathrm{m}$ ). This feature clearly separates Species 145 from all other species (Table 2, Fig. 5f).

\section{Taxonomic diversity of Weddell Sea Gromia}

The Weddell Sea specimens constitute the most extensive and diverse available collection of deep-sea gromiids. Recently, the number of formally described deep-sea species increased from three (G. sphaerica, G. pyriformis, and G. schulzei) to six with the establishment of G. marmorea, G. melinus, and G. winnetoui by Rothe et al. (2009) (Table 3 ). In this paper, we recognize a further nine species from the Weddell Sea on the basis of morphological criteria (Table 3). This number compares to the eight undescribed species from the Arabian Sea that were recognized based on SSU rDNA gene sequences (Aranda da Silva et al. 2006), three gromiids from $923 \mathrm{~m}$ under the Ross Ice Shelf (Pawlowski et al. 2005), sixteen morphospecies from the North and Northeast Atlantic (Rothe
2009), an elongate, dark morphotype from the Svalbard margin (Gooday et al. 2005, Fig. 2d), and the "faecal pellet" from the Santa Catalina Basin in the Northeast Pacific (Jumars 1976; Table 3).

Despite an increasing number of studies, it remains difficult to assess the scale of diversity within the genus Gromia. Some deep-sea gromiids may have been misidentified as allogromiid foraminiferans as a result of the paucity of characters available to differentiate between the two groups. Allogromiids are very abundant in the World's oceans, and some illustrations of small, organic-walled specimens (e.g. Fig. 3A-C in Gooday 1986) could represent gromiids, potentially increasing the number of species substantially. Collections from particular areas, for example the NE Atlantic as well as the Weddell Sea, indicate relatively high regional diversity. Cryptic speciation, for which there is molecular evidence in the case of the shallow-water species G. oviformis (Burki et al. 2000), would increase diversity at large, spatial scales further. On the other hand, the recent discovery, confirmed by molecular analysis, of $G$. sphaerica in the Bahamas (Matz et al. 2008), and the morphological similarity between Jumars' "faecal pellet" from the Northeast Pacific and an Arabian Sea species, suggests that some species are widely distributed, thereby depressing global diversity estimates. More detailed morphological and genetic analyses, as well as a considerable sampling 
Fig. 5 Undescribed of Gromia. a Reflected light photograph of Species 5B, Station 150, 1,970 m depth. b Oral capsule photographed in transmitted light; c oral capsule photographed in transmitted light; d reflected light photograph of Species 154, Station 102,

$\sim 4,800 \mathrm{~m}$ depth; e oral capsule photographed in reflected light; f reflected light photograph of Species 145, Station 80, $\sim 3,108 \mathrm{~m}$ depth; $\mathbf{g}$ oral capsule photographed in transmitted light
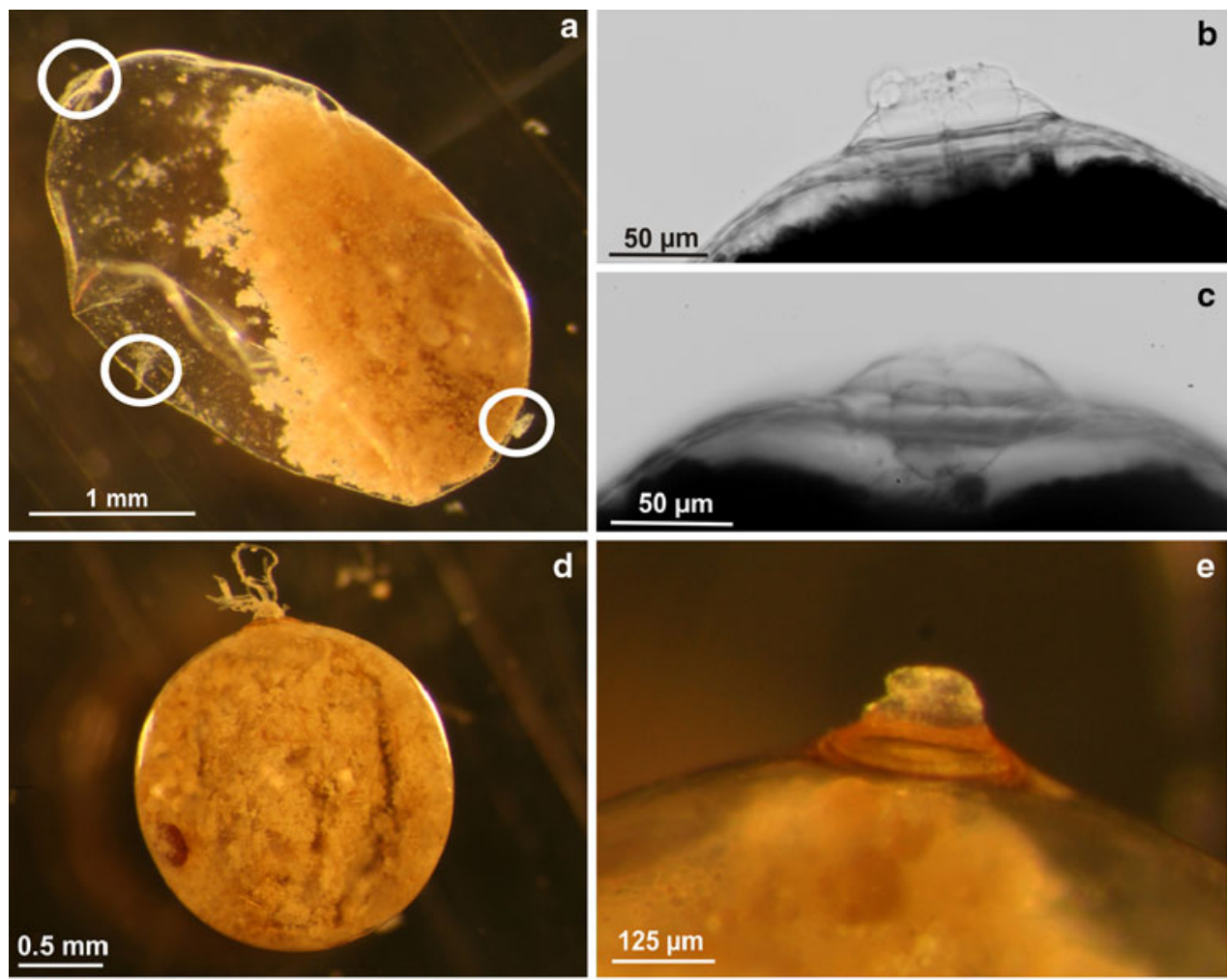

d
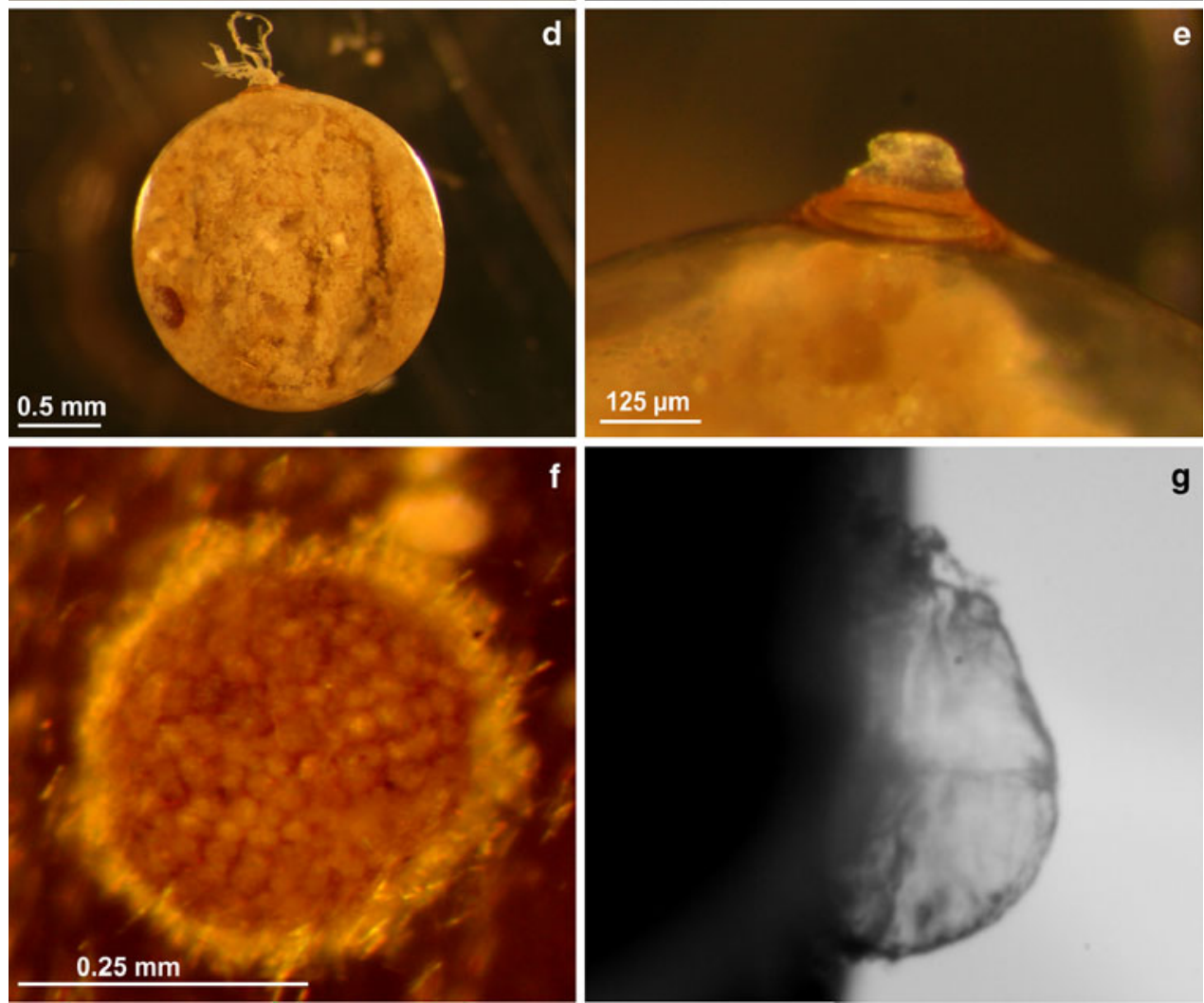

effort, are required before any attempt can be made to estimate the global diversity of gromiids.

\section{Geographic and bathymetric distribution}

Published and unpublished reports indicate that gromiids occur at depths $>200 \mathrm{~m}$ on continental margins around the globe (Fig. 6). The ANDEEP III transect across the Weddell Sea was the first consistently conducted survey of gromiids from a continental slope to an adjacent abyssal plain. It demonstrated that gromiids occur on abyssal plains, albeit at a much lower density and diversity than on the bathyal margin (Fig. 7). The deep Weddell Sea gromiids were found predominantly at bathyal depths, except for
Species 154 and G. melinus, which occurred down to $\sim 4,800 \mathrm{~m}$ (Table 1, Fig. 8). Most of the stations where gromiids were found were characterized by muddy sediments with a surface layer of phytodetritus with $25-75 \%$ coverage (Diaz 2004-Table 4 herein). However, there was no link between the amount of organic matter accumulated on the seafloor and gromiid abundances. For example, seabed images of abyssal stations close to Station 102 $(4,800 \mathrm{~m})$ showed a layer of recent phytodetritus covering as much as $75 \%$ of the sediment surface. Nevertheless, only two specimens were sampled at this station compared to $\sim 700$ specimens at Station $133(1,584 \mathrm{~m})$ with $25 \%$ coverage of phytodetritus (Diaz 2004-Tables 1, 4 herein). Despite these observations, it seems likely that food availability 
Table 3 Sample locations of all formally described species and informally recognized species of deep-sea Gromia (>200 m)

\begin{tabular}{|c|c|c|}
\hline Location & Formally described species & Undescribed morphotypes \\
\hline Weddell Sea & $\begin{array}{l}\text { G. marmorea }(1,584 \mathrm{~m}), \text { G. melinus } \\
(3,103+4,392 \mathrm{~m}), \text { G. winnetoui } \\
(2,600 \mathrm{~m}) \text { (Rothe et al. 2009) }\end{array}$ & $\begin{array}{l}1 \mathrm{~A}, 76,297,1 \mathrm{~B}, 2,5 \mathrm{~A}, 5 \mathrm{~B}, 154,145 \\
(1,140-4,800 \mathrm{~m})(\text { Rothe } 2009)\end{array}$ \\
\hline Ross Sea & & $\begin{array}{l}\text { Three gromiids under Ross Ice Shelf } \\
\quad(923 \mathrm{~m}) \text { (Pawlowski et al. 2005) }\end{array}$ \\
\hline Arabian Sea & $\begin{array}{l}\text { G. sphaerica }(1,100-1,852 \mathrm{~m}) \\
\text { (Gooday et al. 2000), G. pyriformis } \\
(\sim 1,000 \mathrm{~m}) \text { (Gooday and Bowser } 2005)\end{array}$ & $\begin{array}{l}\text { Species } 1,2,3,4,5,6,7,8(1,093-2,075 \mathrm{~m}) \\
\quad(\text { Aranda da Silva 2005) }\end{array}$ \\
\hline \multicolumn{3}{|l|}{ Northeast Atlantic } \\
\hline Rockall Trough & & $\mathrm{A} 1, \mathrm{~A} 2, \mathrm{~B} 1, \mathrm{C} 1, \mathrm{C} 4$ \\
\hline Porcupine Seabight & & $\mathrm{A} 2, \mathrm{C} 2, \mathrm{C} 3, \mathrm{D} 1$ \\
\hline Northwest African Margin & & D2 (1,028-3,000 m) (Rothe 2009) \\
\hline Northwest Atlantic & & $\begin{array}{l}\text { Gromiid off South Georgia 185-675 m) } \\
\quad \text { (Arnold 1972) }\end{array}$ \\
\hline Bahamas & G. sphaerica $(\sim 750 \mathrm{~m})$ (Matz et al. 2008) & \\
\hline $\begin{array}{l}\text { Western Norwegian fjords, } \\
\text { Skagerrak }\end{array}$ & G. schulzei (165-675 m) (Schulze 1875) & A3, A4, B2, C5, C6, C8 (515-664 m) (Rothe 2009) \\
\hline Svalbard & & Elongate dark gromiid (313 m) (Gooday et al. 2005) \\
\hline Northeast Pacific & & "Faecal pellet" (1,130 m) (Jumars 1976) \\
\hline
\end{tabular}

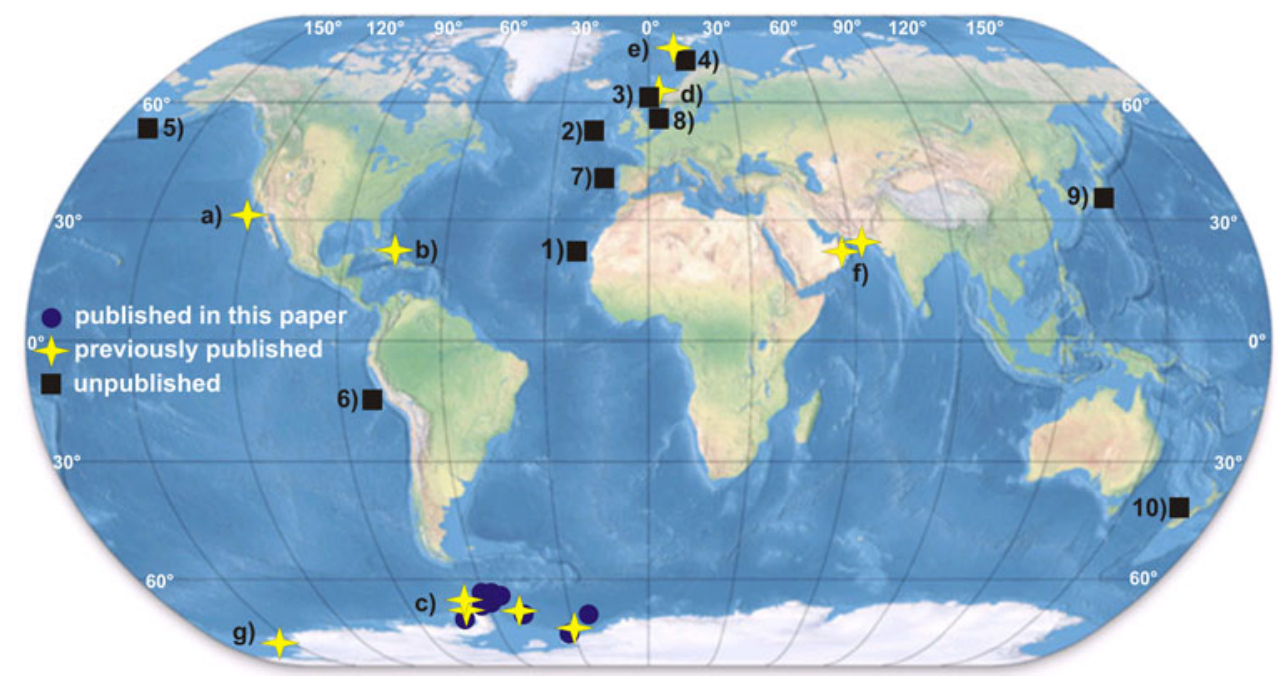

Fig. 6 Worldwide distribution of deep-sea gromiids. Previously published records include a "faecal pellet" from the Santa Catalina Basin in the Northeast Pacific (1,130 m) (Jumars 1976); b G. sphaerica from the Bahamas (750-780 m) (Matz et al. 2008); c gromiid from $270 \mathrm{~m}$ depth off South Georgia (Arnold 1972); d G. schulzei from the Bukenfjord (185-674 m) (Schulze 1875); e dark, elongate gromiid from the Svalbard margin (Gooday et al. 2005); f G. sphaerica (1,100-1,852 m) and G. pyriformis $(\sim 1,000 \mathrm{~m})$ from the Arabian Sea (Gooday et al. 2000; Gooday and Bowser 2005); $\mathbf{g}$ gromiids from 923 m depth under the Ross Ice Shelf, Antarctica (Pawlowski et al. 2005). Unpublished

influences the abundance of gromiids in the Weddell Sea. A strong link exists between the availability of labile food derived from surface primary production and the population size (biomass) of foraminifera (Gooday and Turley 1990; Altenbach 1992; Ohga and Kitazato 1997; Gooday records are from the 1 continental margin off Western Sahara (1,300 m) (Rothe 2009); 2+3+4 the Porcupine Seabight, the Rockall Trough, and the Møre fjords off Norway (Rothe 2009); 5 Unimak margin off Alaska (3,283 m) (L. Levin, pers. comm.); 6 the margin off Peru $(2,410 \mathrm{~m})$ (T. Cedhagen, pers. communication); 7 the Nazaré Canyon off Portugal ( 2,200-3,951 m) (A. J. Gooday, unpublished); 8 Håkon Mosby mud volcano (O. Kamenskaya and A. J. Gooday, unpublished); 9 Sagami Bay $(\sim 1,400 \mathrm{~m})$, Japan (H. Kitazato, pers. comm.); 10 off New Zealand (L. Levin, pers. comm.)

and Rathburn 1999; Kitazato et al. 2000), as well as their distribution patterns (Altenbach and Sarnthein 1989; Gooday 1993).

The Weddell Sea gromiids were concentrated at depths similar to those $(1,093-2,128 \mathrm{~m})$ at which gromiids were 
Fig. 7 Circles represent gromiid sample stations in the Weddell Sea. Size of each circle corresponds to the number of specimens found at each station
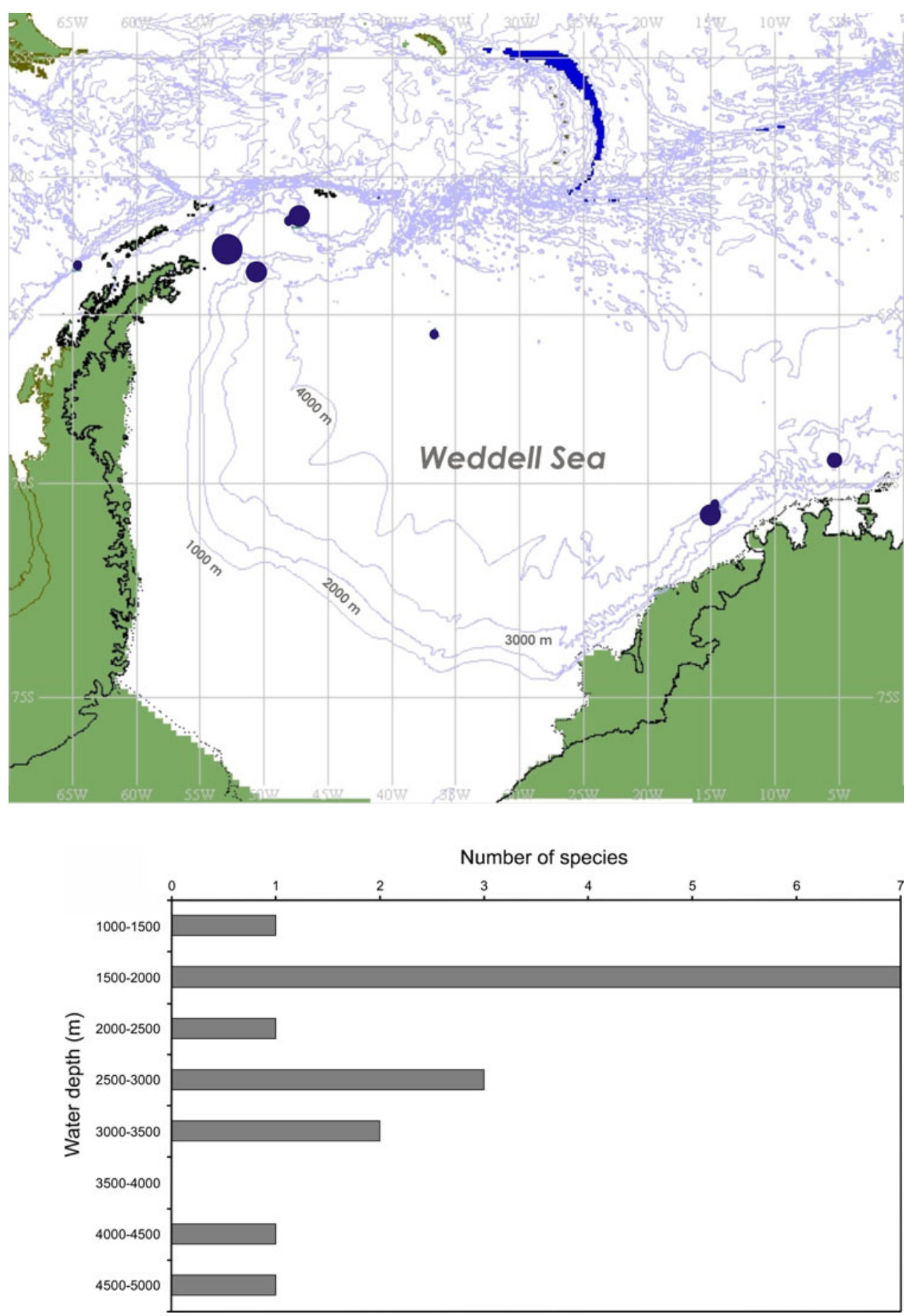

Fig. 8 Bathymetric distribution of Weddell Sea gromiids $\sim 0.2 \mathrm{ml} / 1$ and where temperatures were below $\sim 10^{\circ} \mathrm{C}$ (Aranda da Silva 2005). In the Weddell Sea, dissolved oxygen concentrations of the bottom waters are comparatively high, ranging between $\sim 3.9$ and $5.4 \mathrm{ml} / \mathrm{l}$ throughout the water column with the highest values observed on the continental margin (Orsi and Whitworth III 2005) (Table 4). Therefore, oxygen is probably not a limiting factor for gromiids in the Southern Ocean. Little is known about the temperature tolerances of deep-sea gromiids. 


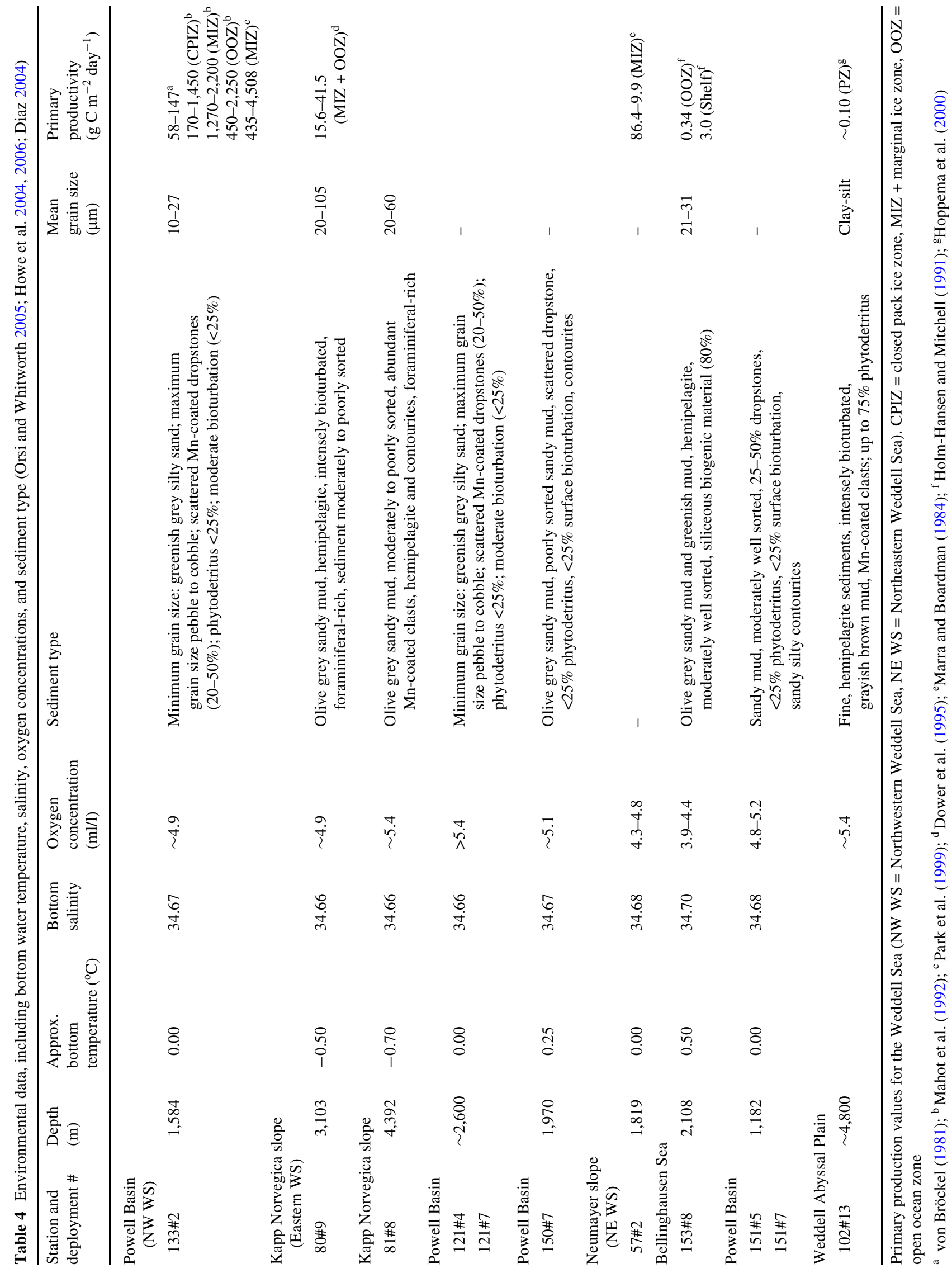


The shallow-water G. oviformis appears to tolerate a wide range of temperatures, ranging from -1.86 to $30^{\circ} \mathrm{C}$ (Arnold 1972; Bowser et al. 1996), although this may reflect the existence of cryptic species within this widely distributed gromiid (Burki et al. 2002).

\section{Concluding remarks}

Until recently, Gromia was known only from shallow waters and most gromiids were assigned to a single species, G. oviformis (Burki et al. 2002). It would appear that gromiids have been frequently overlooked in deep-sea samples, in some cases being mistaken for faecal pellets (e.g. Jumars 1976) or allogromiids (e.g. Gooday 1986). The present study, based on the largest available collection of deep-sea gromiids examined to date, has significantly increased the number of known species. It includes the deepest record for a gromiid $(\sim 4,800 \mathrm{~m})$ extending the bathymetric range of the genus Gromia to abyssal depths. Although gromiids seem to be particularly common in areas of high productivity, ambiguities still remain regarding their wider ecological role. It has been suggested that deep-sea gromiids play an important role in carbon cycling in bathyal eutrophic regions of the World's oceans through the ingestion and degradation of fresh organic matter (Aranda da Silva 2005). Piña-Ochoa et al. (2010) reported that gromiids collected between 37 and $450 \mathrm{~m}$ depth at various sites around the globe were able to accumulate and respire nitrate through denitrification. Their observations are supported by similar work on gromiids from Sagami Bay, Japan (Hiroshi Kitazato, pers. comm.), and suggest that gromiids may play an important role in global nitrogen cycling as well as carbon cycling.

Acknowledgments We thank Prof. Angelika Brandt for inviting two of us (AJG and TC) to participate in the ANDEEP III expedition, and for making available material from the EBS and the AGT, Dr. Eberhard Fahrbach for the efficient running of the RV Polarstern ANTXXII/3 cruise, and the Captain, officers, and crew of the RV Polarstern for their help during the cruise. Professor Christoffer Schander is thanked for organizing the BIOSKAG and MØRE expeditions to the Skagerrak and west Norwegians fjords where additional material was sampled. We also thank Prof. Lisa Levin and Prof. Hiroshi Kitazato for permission to report unpublished gromiid records, as well as the reviewers (Drs Ana Aranda da Silva, Sam Bowser and Olga Kamenskaya) for their helpful comments. This research was supported by the Natural Environment Research Council, UK, project Ocean 2025. This is ANDEEP publication \# 143.

\section{References}

Altenbach AV (1992) Short term processes and patterns in the foraminiferal response to organic carbon flux rates. In: van der Zwaan GJ, Jorisson FJ, Zachariasse WJ (eds) Approaches of paleoproductivity reconstructions. Mar Micropaleontol 19:119-129
Altenbach A, Sarnthein M (1989) Productivity record in benthic Foraminifera. In: Berger WH, Smetacek V, Wafer G (eds) Productivity of the ocean: present and past. Wiley, New York, pp 255-270

Aranda da Silva A (2005) Benthic protozoan community attributes in relation to environmental gradients in the Arabian Sea. Dissertation, University of Southampton

Aranda da Silva A, Gooday AJ (2009) Large organic-walled Protista (Gromia) in the Arabian Sea: density, diversity, distribution and ecology. Deep Sea Res Part II 56:422-433

Aranda da Silva A, Pawlowski J, Gooday AJ (2006) High diversity of deep-sea Gromia from the Arabian Sea revealed by small subunit rDNA sequence analysis. Mar Biol 148:769-777

Arnold ZM (1951) Occurrence of Gromia oviformis Dujardin in California (Testacea). J Biol 9:351-353

Arnold ZM (1972) Observations on the biology of the protozoan Gromia oviformis Dujardin. Univ Calif Publ Zool 100:1-168

Bowser SS, Marko M, Bernhard JM (1996) Occurrence of Gromia oviformis in McMurdo Sound. Antarct J US 31:122-124

Burki F, Berney C, Pawlowski J (2002) Phylogenetic position of Gromia oviformis Dujardin inferred from nuclear-encoded small Subunit Ribosomal DNA. Protist 153:251-260

Diaz RJ (2004) Biological and physical processes structuring the deepsea surface sediments in the Scotia and Weddell Seas, Antarctica. Deep Sea Res Part II 51:1515-1532

Dower KM, Lucas MI, Phillips R, Dieckmann G, Robinson DH (1995) Phytoplankton biomass, P-I relationships and primary production on the Weddell Sea, Antarctica, during the Austral autumn. Polar Biol 16:41-52

Dujardin F (1835) Observations nouvelles sur les Céphalopodes microscopiques. Ann Sci Nat, Paris Zool 3:108-109

Fahrbach E (2006) The Expedition ANTARKTIS-XXII/3 of the Research Vessel "Polarstern" in 2005. Ber Polar- Meeresforsch 533:1-246

Gooday AJ (1986) Meiofaunal foraminiferans from the bathyal Porcupine Seabight (northeast Atlantic): size structure, standing stock, taxonomic composition, species diversity and vertical distribution in the sediment. Deep Sea Res Part II 33:1345-1373

Gooday AJ (1993) Deep-sea benthic foraminiferal species which exploit phytodetritus: characteristic features and controls on distribution. Mar Micropaleaontol 22:187-205

Gooday AJ, Bowser SS (2005) The second Gromia species (testate amoeba) from the deep sea: its natural history and association with the Pakistan margin oxygen minimum zone. Protist 156:113-126

Gooday AJ, Rathburn AE (1999) Temporal variability in living deepsea benthic Foraminifera: a review. Earth Sci Rev 46:187-212

Gooday AJ, Turley M (1990) Responses by benthic organisms to inputs of organic material to the ocean floor: a review. Philos Trans R Soc Lond A 331:119-138

Gooday AJ, Bowser SS, Bernhard JM (1996) Benthic foraminiferal assemblages in Explorers Cove, Antarctica: a shallow water site with deep-sea characteristics. Progr Oceanogr 37:117-166

Gooday AJ, Bowser SS, Bett BJ, Smith CR (2000) A large testate protist, Gromia sphaerica sp nov (Order Filosea), from the bathyal Arabian Sea. Deep Sea Res Part II 47:55-73

Gooday AJ, Bowser SS, Cedhagen T, Cornelius N, Hlad M, Korsun S, Pawlowski J (2005) Monothalamous foraminiferans and gromiids (Protista) from western Svalbard: a preliminary survey. Mar Biol Res 1:290-312

Gooday AJ, Cedhagen T, Cornelius N (2006) Diversity and biogeography of deep-sea benthic Foraminifera-a combined molecular and morphological approach. In: Fahrbach E (ed) The Expedition ANTARKTIS-XXII3 of the Research Vessel "Polarstern" in 2005. Ber Polar- Meeresforsch 533:88-93

Hedley RH (1960) The iron-containing shell of Gromia oviformis (Rhizopoda). Q J Microsc Sci 101:279-293 
Hedley RH, Bertaud WS (1962) Electron-microscopic observations of Gromia oviformis (Sarcodina). J Protozool 91:79-97

Hedley RH, Wakefield JSJ (1969) Fine structure of Gromia oviformis (Rhizopodea: Protozoa). Bull Nat Hist Mus Zool 18:69-89

Holm-Hansen O, Mitchell BG (1991) Spatial and temporal distribution of phytoplankton and primary production in the Western Bransfield Strait region. Deep Sea Res Part II 38:961-980

Hoppema M, Goeyens L, Fahrbach E (2000) Intense nutrient removal in the remote area off Larson Ice Shelf (Weddell Sea). Polar Biol 23:85-94

Howe JA (2006) Recent sedimentation and geochemistry across the Northern Weddell Sea and adjacent deep-water regions, Antarctica. In: Fahrbach E (ed) The Expedition ANTARKTIS-XXII3 of the Research Vessel "Polarstern" in 2005. Ber Polar- Meeresforsch 533:196-208

Howe JA, Shimmield TM, Diaz R (2004) Deep-water sedimentary environments of the northwestern Weddell Sea and South Sandwich Islands, Antarctica. Deep Sea Res Part II 51:1489-1514

Jepps MW (1926) Contribution to the study of Gromia oviformis Dujardin. Q J Microscop Sci 70:701-719

Jumars PA (1976) Deep-sea species diversity: does it have a characteristic scale? J Mar Res 34:217-246

Kitazato H, Shirayama Y, Nakatsuka T, Fujiwara S, Shimanaga M, Kato Y, Okada Y, Kanda J, Yamaoka A, Masuzawa T, Suzuki K (2000) Seasonal phytodetritus deposition and responses of bathyal benthic foraminiferal populations in Sagami Bay, Japan: preliminary results from "Project Sagami 1996-1999". Mar Micropaleontol 40:135-149

Mahot S, Dandpis JM, Lancelot C (1992) Gross and net primary production in the Scotia-Weddell Sea sector of the Southern Ocean during spring 1988. Polar Biol 12:321-332

Marra J, Boardman DC (1984) Late winter chlorophyll a distributions in the Weddell Sea. Mar Ecol Prog Ser 19:197-205

Matz MV, Frank TM, Marshall NJ, Widder EA, Johnson S (2008) Giant deep-sea protist produces bilaterian-like traces. Curr Biol 18:1849-1854

Norman AM (1892) Museum Normanium, pt 7-8, 15 pp, Durham, England
Odgen CG, Hedley RH (1980) An atlas of freshwater testate amoebae. Oxford University Press, London

Ohga T, Kitazato H (1997) Seasonal changes in bathyal foraminiferal populations in response to the flux of organic matter (Sagami Bay, Japan). Terra Nova 9:33-37

Orsi AH, Whitworth T III (2005) Hydrographic Atlas of the World Ocean Circulation Experiment (WOCE), vol 1. In: Sparrow M, Chapman P, Gould J (eds) Southern Ocean. International WOCE Project Office, Southampton, UK

Park MG, Yang SR, Kang S-H, Chung KH, Shim JH (1999) Phytoplankton biomass and primary production in the marginal ice zone of the northwestern Weddell Sea during the Austral summer. Polar Biol 21:251-261

Pawlowski J, Fahrni JF, Guiard J, Conlan K, Hardecker J, Habura A, Bowser SS (2005) Allogromiid foraminifera and gromiids from under the Ross Ice Shelf: morphological and molecular diversity. Polar Biol 28:514-522

Piña-Ochoa E, Høgslund S, Geslin E, Cedhagen T, Revsbech NP, Nielsen LP, Schweizer M, Jorissen F, Rysgaard S, RisgaardPetersen N (2010) Widespread occurrence of nitrate storage and denitrification among Foraminifera and Gromiida. Proc Natl Acad Sci USA 107:1148-1153

Rose A, Cornelius N, DeMesel, I, Doner S, Gooday AJ, Henche A, Howe JA, Ingels J, Narayanaswamy BE (2006) Introduction to work at sea: Multicorer sampling during ANDEEP III. In: Fahrbach E (ed) The Expedition ANTARKTIS-XXII3 of the Research Vessel "Polarstern" in 2005. Ber Polar- Meeresforsch 533:85-87

Rothe N (2009) Systematics and biogeography of Antarctic deep-sea gromiids. Dissertation, University of Southampton

Rothe N, Gooday AJ, Cedhagen T, Fahrni J, Hughes A, Page A, Pearce R, Pawlowski J (2009) Three new species of deep-sea Gromia (Protista, Rhizaria) from the bathyal and abyssal Weddell Sea, Antarctica. Zool J Linn Soc 157:451-469

Schulze FE (1875) Gromia sp. Jahresbericht der Comm. zur wissenschaft. Unters. der deutschen Meere in Kiel, pp 1872-1873

Von Bröckel K (1981) The importance of nanoplankton within the pelagic Antarctic ecosystem. Kiel Meeresforsch Sonderh 5:61-67 